\title{
Growth-Depressing Effect of Alfalfa Saponin in Chicks
}

\author{
Hiroshi UEDA, Yoshinori KAKUTOU \\ and Mitsuaki OHSHIMA* \\ College of Agriculture, Ehime University, Matsuyama-shi 790 \\ * University Farm, Faculty of Agriculture, Nagoya University, \\ Togo-cho, Aichi-ken 470-01
}

(Received April 1, 1996)

\begin{abstract}
Effects of alfalfa saponin with or without cholesterol on chick growth performance, feed palatability and passage time of ingesta were investigated. The addition of $1 \%$ alfalfa saponin to the basal dict containing casein (CP 20\%) decreased feed intake and body weight gain. These adverse effects were overcome by adding $1 \%$ cholesterol simultaneously with saponin. Dietary saponin was effective in lowering the elevated cholesterol and triglyceride concentrations in the serum caused by the addition of cholesterol. To avoid the effect of taste sensation, saponin was capsuled and introduced directly into the proventriculus. The administration of $0.5 \mathrm{~g}$ alfalfa saponin depressed feed and water intake during $24 \mathrm{~h}$ as compared to untreated chicks. These deleterious effects were alleviated by the addition of cholesterol, irrespective of whether cholesterol was included in capsules $(0.5 \mathrm{~g})$ or in the diet $(1 \%)$. Chicks were tube-fed diets containing chromic oxide, and the passage time of ingesta was compared for $24 \mathrm{~h}$. Adding $1 \%$ saponin to the basal diet decreased chromic oxide excretion by approximately half. Reflecting this, the crop in saponin-fed chicks was expanded with ingesta. Besides, feed intake was still suppressed when these chicks were given free access to the basal diet. These abnormalities were completely recovered by the simultaneous addition of cholesterol with saponin. These results suggest that the adverse effect of alfalfa saponin and its alleviation by cholesterol are related to the passage time of ingesta, and not to the feed palatability.
\end{abstract}

Anim. Sci. Technol. (Jpn.) 67 (9) : 772-779,1996

Key words ; Alfalfa saponin, Feed palatability, Feed passage. Serum and liver lipids

Feeding diets high in alfalfa saponin depresses growth rate in chicks and such growth depression is always associated with reduced feed intake $1,3,10,15,16,18,20)$. This suggests that alfalfa saponin adversely affects growth rate by suppressing feed intake. However, the mechanism by which alfalfa saponin reduced feed intake remains unclear.

Saponin has been considered to lend bitterness, although there is little quantitative data available in this regard. According to Cheeke $^{3)}$, the high saponin alfalfa is bitter and astringent when chewed by humans. Thus, it is possible to suggest that the unfavorable effect of alfalfa saponin is primarily to reduce the palatability of feeds. It has been reported that chicken can detect the bitterness because they reject diets containing quinine sulfate ${ }^{4}$. However, these chickens could not discriminate the difference in saponin content when they were offered a choice of diets containing different levels of saponin ${ }^{4}$. On the other hand, rats preferentially select low-saponin diets in the two-choice preference test ${ }^{2)}$. These results contrasted with our previous finding ${ }^{(0)}$ that chicks were more sensitive to 
dietary alfalfa saponin than rats.

A simultaneous addition of cholesterol with alfalfa saponin has overcome the depressed feed intake and growth retardation due to this saponin ${ }^{1,12,15,16)}$. However, there has been no evidence that cholesterol alters the feed palatability. We thus considered that feed palatability is not a primary determinant responsible for the depressed feed intake.

Reshef et al. ${ }^{12)}$ have reported that neither saponin nor sapogenin is found in the blood in animals fed diets containing alfalfa saponin. It seems unlikely, therefore, that alfalfa saponin absorbed from the intestine affects the feed intake regulatory system.

Alfalfa preparations are known to have a hypocholesterolemic effect in chicks ${ }^{3,9,16,17,20)}$, It has been suggested that this hypocholesterolemic effect is due to the formation of an insoluble cholesterol-saponin complex (cholesterol saponide) in the intestinal tract ${ }^{11}$. Indeed, alfalfa saponin binds cholesterol in vitro $^{5,14)}$, and it inhibits the cholesterol absorption and increases fecal neutral steroid excretion in vivo, ${ }^{8,12,14}$. This property may explain the interactive effect of saponin and cholesterol on feed intake.

The present experiment was conducted on chicks to investigate the effects of alfalfa saponin with or without cholesterol on growth performance, feed palatability and passage time of ingesta.

\section{Materials and Methods}

Saponin was extracted from root of alfalfa (Medicago sativa, cv. Dupuits) by the method of Shany et $a l{ }^{13)}$.

Table 1 shows the composition of basal diets containing different levels of corn oil. All diets were formulated to provide $20 \%$ crude protein. At the expense of glucose, $1 \%$ alfalfa saponin and/or $1 \%$ cholesterol were added to each basal diet.

Single Comb White Leghorn male chicks were maintained in a room with constant tem-
Table 1. Composition of basal diets

\begin{tabular}{|c|c|c|}
\hline Dietary component & Low fat diet & High fat diet \\
\hline & \multicolumn{2}{|c|}{$(g / \mathrm{kg}$ diet $)$} \\
\hline Casein & \multicolumn{2}{|c|}{209.1} \\
\hline L-Arginine hydrochloride & \multicolumn{2}{|c|}{12.4} \\
\hline DL-Methionine & \multicolumn{2}{|c|}{3.9} \\
\hline Glycine & \multicolumn{2}{|r|}{4.6} \\
\hline Vitamin $\operatorname{mix}^{*}$ & \multicolumn{2}{|c|}{1.0} \\
\hline Choline chloride & \multicolumn{2}{|r|}{2.0} \\
\hline Mineral mix* & \multicolumn{2}{|c|}{65.2} \\
\hline Cellulose & \multicolumn{2}{|c|}{100.0} \\
\hline Corn oil & 20.0 & 120.0 \\
\hline Glucose, anhydrous & 581.8 & 481.8 \\
\hline
\end{tabular}

* Ueda et al. ${ }^{21)}$.

perature $\left(30^{\circ} \mathrm{C}\right)$ and continuous lighting. They were raised on a commcrcial chick startcr ration in wire-mesh cages from hatch to the beginning of each experiment. During this time, the restricted pre-feeding program ${ }^{217}$ was applied to chicks used in Experiment 1 and the ad libitum feeding to those used in Experiments 2 and 3 . The necessary number of chicks with similar weight was selected from the stock at the beginning of each experiment. They were housed individually in metabolism cages during the experimental period.

Effects of dietary alfalfa saponin with or without cholesterol on growth performance and cholesterol and triglyceride concentrations in the serum or liver were studied in Experiment 1. The hypocholesterolemic effect of soybean saponin was modified by dietary fat content ${ }^{22)}$. In this experiment, thus, two diets containing different levels of corn oil were used. Seven-day-old chicks were divided into 8 experimental groups of 6 chicks cach. They were provided ad libitum access to respective diets and water for 12 days. At the end of the feeding experiment, chicks were deprived of feed for $5 \mathrm{~h}$, and their body weights and feed intake were recorded. Blood was obtained by heart puncture and centrifuged at 3,500 rpm for 10 min after coagulation to separate serum. Livers were excised after decapitation. They 
were rinsed with sodium chloride solution $(8.5$ $\mathrm{g} / l)$, blotted, weighed and stored at $-20^{\circ} \mathrm{C}$ until analysis.

In Experiments 2 and 3,19-day-old chicks were used. They were deprived of feed overnight (for $15 \mathrm{~h}$ ). Chicks used for Experiment 2 were divided into 5 experimental groups of 5 chicks each. Three groups were administered gelatin capsules containing either of saponin $(0.5 \mathrm{~g})$ or cholesterol $(0.5 \mathrm{~g})$, or both, and then all chicks were fed the cholesterol-free diet (high fat diet in Table 1). The remaining groups were either fed the cholesterol-free diet or given capsules containing $0.5 \mathrm{~g}$ saponin in combination with feeding with the $1 \%$ cholesterolsupplemented diet. Capsules were carefully inserted into the proventriculus to avoid the effect of taste sensation. Chicks had free access to diets and distilled water for $24 \mathrm{~h}$, during which feed and water intake were recorded at time intervals and compared with that of untreated chicks fed the cholesterolfree diet.

Experiment 3 was carried out using chromic oxide $\left(\mathrm{Cr}_{2} \mathrm{O}_{3}\right)$ to determine effects of alfalfa saponin and cholesterol on passage time of ingesta. Three groups of 6 chicks were tubefed the high fat diet, or this diet containing $1 \%$ saponin together with or without $1 \%$ cholesterol for 2 days. Five $g$ of each diet were mixed with approximately $8 \mathrm{~m} l$ distilled water and introduced into the crop 4 times per day at an interval of $4 \mathrm{~h}$. The first meal on the second day was added with $35 \mathrm{mg} \mathrm{Cr}_{2} \mathrm{O}_{3}$ and excreta were collected in a tray periodically for $24 \mathrm{~h}$ to determine the excreted $\mathrm{Cr}_{2} \mathrm{O}_{3}$. On the third day of the experiment, chicks were allowed to eat the saponin-free diet ad libilum for $6 \mathrm{~h}$ and feed intake was recorded.

Cholesterol and triglyceride concentrations in the serum and liver were measured with enzymatic procedures as reported previously ${ }^{21)}$. Determination of $\mathrm{Cr}_{2} \mathrm{O}_{3}$ was made by the method of Hill and Anderson ${ }^{6)}$. Statistical analysis was done using the analysis of variance, and comparisons among treatments were made by Tukey's multiple range test ${ }^{23)}$.

\section{Results}

Body weight gain was higher in chicks fed high fat diets than in those fed low fat diets (Table 2). The addition of $1.0 \%$ saponin to cholesterol-free diets depressed body weight gain and feed intake, irrespective of dietary fat content. The simultaneous addition of $1.0 \%$ cholesterol with saponin completely alleviated the depression in body weight gain and feed intake. These changes were observed within two days after the commencement of the expcriment.

As shown in Table 2, when cholesterol was added to saponin-free diets, serum cholesterol concentrations were higher in chicks fed high fat diets than in those fed low fat diets. Although adding saponin to cholesterol-free diets did not alter serum cholesterol concentrations, saponin in cholesterol-supplemented diets lowered partly the elevated serum cholesterol.

Without the addition of cholesterol, serum triglyceride concentrations were not affected by supplementing with saponin, but decreased by feeding high fat diets (Table 2). The addition of cholesterol to high fat diets increased serum triglyceride concentrations to the levels comparable to chicks fed low fat diets. Dietary saponin reduced serum triglyceride concentrations in cholesterol-fed chicks, independently of dietary fat levels.

Cholesterol or triglyceride content in the liver is given in Table 3 . Relative liver weight was increased by adding cholesterol to high fat diets. Liver cholesterol content in chicks fed cholesterol-free diets was not affected by dietary saponin or fat levels. The addition of cholesterol to saponin-free diets increased liver cholesterol content, the extent of which was much higher in chicks fed high fat diets than in those fed low fat diets. Saponin added to diets containing cholesterol slightly reduced 


\section{Growth-Depressing Effect of Alfalfa Saponin}

Table 2. Effects of alfalfa saponin and cholesterol on growth performance and cholesterol and triglyceride concentrations in the serum of chicks fed diets containing different levels of fat (Experiment 1)

\begin{tabular}{|c|c|c|c|c|c|c|}
\hline \multirow[b]{2}{*}{ Fat } & \multirow[b]{2}{*}{$\begin{array}{c}\text { Saponin } \\
(\%)\end{array}$} & \multirow[b]{2}{*}{$\begin{array}{c}\text { Cholesterol } \\
(\%)\end{array}$} & \multirow{2}{*}{$\begin{array}{c}\text { Body } \\
\text { wt gain }\end{array}$} & \multirow{2}{*}{$\begin{array}{l}\text { Feed } \\
\text { intake }\end{array}$} & \multicolumn{2}{|c|}{ Serum } \\
\hline & & & & & $\begin{array}{r}\text { Cholesterol } \\
(\mathrm{mg})\end{array}$ & $\begin{array}{l}\text { Triglyceride } \\
00 \mathrm{ml})\end{array}$ \\
\hline Low & - & - & $91.2^{\mathrm{b}}$ & $199.8^{b}$ & $242^{\mathrm{a}}$ & 49. $9^{b c}$ \\
\hline Low & 1.0 & - & $63.0^{\mathrm{a}}$ & $163.2^{\mathrm{a}}$ & $230^{\mathrm{a}}$ & $45.8^{b}$ \\
\hline High & - & - & 98. $0^{\text {bc }}$ & 198. $3^{b}$ & $233^{\mathrm{a}}$ & $26.8^{a}$ \\
\hline High & 1.0 & - & $74.5^{\mathrm{a}}$ & $166.2^{\mathrm{y}}$ & $200^{\mathrm{a}}$ & 28. $9^{a}$ \\
\hline Low & - & 1.0 & $97.8^{\mathrm{b} c}$ & $214.3^{b}$ & $551^{c}$ & $65.8^{d}$ \\
\hline Low & 1.0 & 1.0 & $95.8^{\mathrm{bc}}$ & $206.3^{b}$ & $424^{b}$ & 50. $9^{b c}$ \\
\hline High & - & 1.0 & $105.5^{c}$ & $206.7^{b}$ & $88 I^{d}$ & $62.6^{\mathrm{cd}}$ \\
\hline High & 1.0 & 1.0 & $100.8^{b c}$ & $194.8^{8}$ & $654^{\mathrm{c}}$ & $46.6^{b}$ \\
\hline Pooled SE & & & 2.6 & 5.4 & 27 & 2.9 \\
\hline \multicolumn{7}{|c|}{ Analysis of variance ${ }^{2)}$} \\
\hline Fat (A) & & & $* *$ & NS & $* *$ & $* *$ \\
\hline Saponin (B) & & & $* *$ & $* *$ & $* *$ & $* *$ \\
\hline $\mathrm{AB}$ & & & NS & NS & NS & NS \\
\hline Cholesterol (C) & & & $* *$ & $* *$ & $* *$ & $* *$ \\
\hline $\mathrm{AC}$ & & & NS & NS & $* *$ & $* *$ \\
\hline $\mathrm{BC}$ & & & $* *$ & ${ }^{* *}$ & $* *$ & * \\
\hline $\mathrm{ABC}$ & & & NS & NS & NS & NS \\
\hline
\end{tabular}

1) Values are means of six chicks each. Means with different superscripts are significantly different at $\mathrm{p}<0.05$.

${ }^{2)} \mathrm{NS}$, not significant ; ${ }^{* *}$ and ${ }^{*}$, significantly different at $\mathrm{p}<0.01$ and 0.05 , respectively.

liver cholesterol content. Liver triglyceride content in chicks fed cholesterol-free diets was not affected by supplemental saponin, but it was apparently lower in chicks fed high fat diets than in those fed low fat diets. Cholesterol added to high fat diets increased liver triglyceride content. Saponin added to diets containing cholesterol reduced liver triglyceride content, irrespective of dietary fat content.

Time course changes of feed and water intake in chicks administered alfalfa saponin in capsules in Experiment 2 are given in Table 4. Chicks given only saponin entirely stopped eating within $4 \mathrm{~h}$ after the administration. However, feed intake increased gradually when saponin was given simultaneously with cholesterol, irrespective of the way of adminis- tration, in capsules or in the diet. Administration of cholesterol alone did not alter the feed intake. The pattern of water consumption showed the tendency similar to that of feed intake.

Table 5 shows the time course change of $\mathrm{Cr}_{2}$ $\mathrm{O}_{3}$ excretion in chicks tube-fed diets containing saponin with or without cholesterol. Chicks given saponin alone decreased $\mathrm{Cr}_{2} \mathrm{O}_{3}$ excretion by approximately half as compared to the control. The pattern of $\mathrm{Cr}_{2} \mathrm{O}_{3}$ excretion in chicks given the diet supplemented with saponin plus cholesterol was entirely comparable to the control. On the third day of this experiment, all chicks were allowed to eat the saponin-free diet ad libitum for $6 \mathrm{~h}$, during which chicks previously fed the diet containing saponin alone ate less $(6.6 \mathrm{~g})$ than other two 
UEDA, KAKUTOU and OHSHIMA

Table 3. Effects of alfalfa saponin and cholesterol on liver weight and cholesterol and triglyceride concentrations in liver of chicks fed diets containing different levels of fat (Experiment 1$)^{t 2}$

\begin{tabular}{|c|c|c|c|c|c|}
\hline Fat & $\begin{array}{c}\text { Saponin } \\
(\%)\end{array}$ & $\begin{array}{c}\text { Cholesterol } \\
(\%)\end{array}$ & $\begin{array}{c}\text { Liver } \\
\text { weight } \\
\text { (mg/g BW) }\end{array}$ & $\begin{array}{c}\text { Liver } \\
\text { cholesterol } \\
(\mathrm{mg} / \mathrm{g})\end{array}$ & $\begin{array}{l}\text { Liver } \\
\text { triglyceride } \\
(\mathrm{mg} / \mathrm{g})\end{array}$ \\
\hline Low & - & - & $34.8^{\mathrm{ab}}$ & $3.8^{\mathrm{a}}$ & $9.3^{\mathrm{cs}}$ \\
\hline Low & 1.0 & - & $35.3^{\mathrm{ab}}$ & $3.7^{\mathrm{a}}$ & 9. $2^{\mathrm{bc}}$ \\
\hline High & - & - & 33. $2^{\mathrm{a}}$ & $3.3^{\mathrm{a}}$ & 6. $2^{\mathrm{ab}}$ \\
\hline High & 1.0 & - & $32.7^{\mathbf{a}}$ & $4,1^{\mathrm{B}}$ & $6.1^{2}$ \\
\hline Low & - & 1.0 & $38.8^{b c}$ & $14.9^{c}$ & 8. $6^{\text {abcd }}$ \\
\hline Low & 1.0 & 1.0 & 37. $5^{\mathrm{abc}}$ & $12.5^{\mathrm{b}}$ & $6.3^{\mathrm{abc}}$ \\
\hline High & - & 1.0 & $39.6^{\mathrm{bc}}$ & $25.6^{\mathrm{d}}$ & $13.4^{\mathrm{e}}$ \\
\hline High & 1.0 & 1.0 & $40.7^{\mathrm{c}}$ & $23.8^{d}$ & $11.5^{\mathrm{de}}$ \\
\hline Pooled SE & & & 1.2 & 0.4 & 0.7 \\
\hline \multicolumn{6}{|c|}{ Analysis of variance ${ }^{2)}$} \\
\hline Fat $(A)$ & & & NS & $* *$ & NS \\
\hline Saponin (B) & & & NS & $*$ & $*$ \\
\hline $\mathrm{AB}$ & & & NS & NS & NS \\
\hline Cholesterol (C) & & & $* *$ & $* *$ & $* *$ \\
\hline $\mathrm{AC}$ & & & $*$ & $* *$ & $* *$ \\
\hline $\mathrm{BC}$ & & & NS & $* *$ & $*$ \\
\hline $\mathrm{ABC}$ & & & NS & NS & NS \\
\hline
\end{tabular}

groups (15.7g).

\section{Discussion}

Alfalfa saponin added to cholesterol-free diets depressed both body weight gain and feed intake, irrespective of the dietary fat content. These unfavorable effects were completely overcome by adding cholesterol to those diets simultaneously with saponin. A similar alleviatory effect of dietary cholesterol has been reported in chicks given alfalfa meal or allalfa leaf protein concentrate (LPC) prepared from high saponin variety ${ }^{1,3,15,16,18)}$. These results support the earlier suggestion ${ }^{11}$ that saponin is the deteriorating factor in alfalfa preparations.

The replacement of casein by alfalfa LPC in diets has been reported to suppress completely the hypercholesterolemia in cholesterol-fed chicks $^{16,20)}$. Dietary alfalfa saponin also pre- vented the elevation of serum cholesterol due to the cholesterol addition in this experiment. In contrast to feeding alfalfa LPC $\operatorname{diets}^{16,20)}$, however, the addition of alfalfa saponin did not return serum cholesterol concentrations to control levels. Alfalfa LPCs contain $0.1 \%$ to $1.9 \%$ saponin $^{7}$. Assuming that alfalfa LPC contains approximately $50 \%$ crude protein ${ }^{17,18)}$, the alfalfa LPC diet providing $20 \%$ protein is calculated to include $0.95 \%$ saponin at most. Thus, the supplemental level of alfalfa saponin in this experiment (1\%) appears to be enough to evaluate the saponin effect. These results indicate that factors other than saponin are responsible for the hypocholesterolemic effect of alfalfa LPC, although alfalfa saponin per se has a cholesterol-lowering effect. Similarly, soybean saponin is not a major determinant factor in the hypocholesterolemic effect of soybean protein preparations ${ }^{22}$ which are 
Growth-Depressing Effect of Alfalfa Saponin

Table 4. Effects of alfalfa saponin and cholesterol administered in capsules (0.5g) or diet (1\%) on cumulative intake of feed and water in chicks fed the high fat diet (Experiment 2) ${ }^{1}$

\begin{tabular}{|c|c|c|c|c|c|c|}
\hline \multirow{2}{*}{ Saponin } & \multirow{2}{*}{ Cholesterol } & \multicolumn{5}{|c|}{ Hours after administration } \\
\hline & & 2 & 4 & 8 & 12 & 24 \\
\hline \multicolumn{7}{|c|}{ Feed intake ( $\mathrm{g} /$ chick) } \\
\hline- & - & $11.2^{\mathrm{c}}$ & $13.4^{\mathrm{c}}$ & $19.8^{c}$ & $24.3^{c}$ & $28.4^{c}$ \\
\hline - & $0.5 \mathrm{~g}$ & 10. $0^{\mathrm{bc}}$ & 13. $6^{\mathrm{c}}$ & $20.1^{\mathrm{c}}$ & $25.0^{\mathrm{c}}$ & $30.4^{\mathrm{c}}$ \\
\hline $0.5 \mathrm{~g}$ & - & $5.8^{\mathrm{a}}$ & $6.4^{\mathrm{a}}$ & $6.4^{\mathrm{a}}$ & $6.4^{\mathrm{a}}$ & $6.4^{\mathrm{a}}$ \\
\hline $0.5 \mathrm{~g}$ & $0.5 \mathrm{~g}$ & $6.0^{\mathrm{a}}$ & 8. $5^{a b}$ & $15.0^{\mathrm{b}}$ & $19.5^{b}$ & $23.6^{\circ}$ \\
\hline $0.5 \mathrm{~g}$ & $1 \%$ in diet & 7. $4^{\mathrm{ab}}$ & 9. $9^{\mathrm{b}}$ & $15.2^{\mathrm{b}}$ & 19. $3^{\mathrm{b}}$ & $24.4^{b}$ \\
\hline Pooled & & 0.7 & 0.8 & 0.9 & 0.8 & 0.9 \\
\hline \multicolumn{7}{|c|}{ Water intake (ml/chick) } \\
\hline- & - & $\mathrm{ND}^{2)}$ & $20.0^{c}$ & $34.8^{c}$ & $46.5^{b}$ & $63.8^{c}$ \\
\hline- & $0.5 \mathrm{~g}$ & ND & 18. $3^{\mathrm{bc}}$ & $31.8^{b c}$ & 43. $0^{b}$ & $60.8^{b c}$ \\
\hline $0.5 \mathrm{~g}$ & $\cdots . .-$ & ND & 9. $8^{\mathrm{a}}$ & 13. $3^{\mathrm{a}}$ & $15.8^{\mathrm{a}}$ & $21.5^{a}$ \\
\hline $0.5 \mathrm{~g}$ & $0.5 \mathrm{~g}$ & $N D$ & $13.5^{a b}$ & $27.5^{b c}$ & $38.5^{b}$ & $51.8^{b}$ \\
\hline $0.5 \mathrm{~g}$ & $1 \%$ in diet & ND & $13.7^{\mathrm{ab}}$ & $24.7^{b}$ & $37.3^{b}$ & $52.7^{\text {bc }}$ \\
\hline Pooled & & - & 1.2 & 2.1 & 2.5 & 2.8 \\
\hline
\end{tabular}

1) Values are means of five chicks each. Means with different superscripts are significantly different at $\mathrm{p}<0.05$.

2) ND; Not determined.

Table 5. Effects of alfalfa saponin and cholesterol on cumulative excretion of chromic oxide in chicks tube-fed the high fat diet (Experiment 3$)^{1)}$

\begin{tabular}{|c|c|c|c|c|c|}
\hline \multirow{2}{*}{$\begin{array}{c}\text { Saponin } \\
(\%)\end{array}$} & \multirow{2}{*}{$\begin{array}{c}\text { Cholesterol } \\
(\%)\end{array}$} & \multicolumn{4}{|c|}{ Hours after administration } \\
\hline & & 4 & 8 & 12 & 24 \\
\hline & & \multicolumn{4}{|c|}{ (mg/chick) } \\
\hline- & - & 2.4 & $17.8^{\mathrm{b}}$ & $21.8^{b}$ & $27.5^{\mathrm{b}}$ \\
\hline 1.0 & - & 1.9 & 7. $8^{a}$ & 10. $4^{\mathrm{a}}$ & 14. $1^{\mathrm{a}}$ \\
\hline 1.0 & 1.0 & 2.8 & $18.9^{b}$ & $23.1^{\circ}$ & $27.2^{\mathrm{b}}$ \\
\hline Pooled SE & & 0.4 & 1.0 & 1.4 & 1.3 \\
\hline
\end{tabular}

1) Values are means of six chicks each. Means with different superscripts are significantly different at $p<0.05$.

other plant proteins showing the hypocholesterolemic effect in chicks ${ }^{19,20)}$.

The hypocholesterolemic effect of soybean saponin was more manifested in chicks fed a diet containing $12 \%$ beef tallow than those fed a beef tallow-free diet in the previous experiment ${ }^{22)}$. Dietary corn oil levels $(2 \%$ and $12 \%$ ), however, did not alter the hypocholesterolemic effect of alfalfa saponin in this experiment although increasing corn oil level elevated serum and liver cholesterol concentrations in cholesterol-fed chicks as observed in those given the beef tallow diet ${ }^{22)}$. It is unclear at present why the hypocholesterolemic effects of alfalfa and soybean saponin are differently affected by the additional fats.

The growth depression caused by feeding alfalfa saponin and its alleviation by the simultaneous addition of cholesterol were accompanied by the alteration of feed intake as 
shown in Experiment 1. The administration of capsules containing alfalfa saponin into the proventriculus depressed feed and water intake as compared to untreated chicks. These adverse effects were alleviated by the addition of cholesterol, irrespective of the way of cholesterol administration, in the capsules or in the diet. Since capsules were introduced directly to the proventriculus and no reflux was observed, we considered that the contents of capsules were not in contact with taste receptors in the oral cavity. These results indicate that the taste sensation does not play an important role in the altered feed intake caused by feeding saponin alone or together with cholesterol.

The change in feed intake seems to be closely related with that of $\mathrm{Cr}_{2} \mathrm{O}_{3}$ excretion as shown in Experiment 3 ; the excretion of $\mathrm{Cr}_{2} \mathrm{O}_{3}$ was suppressed by adding saponin alone to the diet and recovered by the simultaneous addition of cholesterol with saponin. Reflecting this, the crop in chicks tube-fed the diet containing saponin alone was still expanded by ingesta on the morning of the third day even though chicks were deprived of feed for $12 \mathrm{~h}$ from the last meal. Besides, feed intake in these chicks was still suppressed after all chicks used in Experiment 3 were allowed to eat the control diet ad libitum. These results suggest that alfalfa saponin delays the passage time of ingesta, by which feed or water intake is depressed.

\section{References}

1) Anderson JO. Effect of alfalfa saponin on the performance of chicks and laying hens. Poult. Sci., 36: 873-876. 1957.

2) Cheeke PR, Pedersen MW, England DC. Responses of rats and swine to alfalfa saponins. Can. J. Anim. Sci., 58 : 783-789. 1978.

3) Cheeke PR. Biological properties and nutritional significance of legume saponins. In : Leaf protein concentrates. (Telek L, Graham HD eds.) 396-414. Avi Publishing, Connecticut. 1980 .
4) Cheeke PR, Powley JS, Nakaue, HS, Arscott GH. Feed preference responses of several avian species fed alfalfa meal, high- and lowsaponin alfalfa, and quinine sulfate. Can. J. Anim. Sci, $63: 707-710.1983$.

5) Gestetner B, Assa $Y$, Henis $Y$, Tencer $Y$, Rotman M, Birk Y, Bondi A. Interaction of lucerne saponins with sterols. Biochim. Biophys. Acta, 270:181-187. 1972.

6) Hill FW, Anderson DL. Comparison of metabolizable energy and productive energy determinations with growing chicks. J. Nutr., $64: 587-603.1958$.

7) Livingston AL, Knuckles BE, Edwards RE, deFremery D, Miller RE, Kohler GE. Distribution of saponin in alfalfa protein recovery systems. J. Agric. Food Chem., 27 : 362-365. 1979.

8) Malinow MR, McLaughlin P, Stafford C, Livingston AL, Kohler GO, Cheeke PR. Comparative effects of alfalfa saponins and alfalfa fiber on cholesterol absorption in rats. Am. J. Clin. Nutr., 32 : 1810-1812. 1979.

9) Oakenfull D. Saponins in food-A review. Food Chem., $6: 19-40.1981$.

10) Ohshima $M$, Ueda $H$. Effects of some treat ments on the yield and the nutritive value of lucerne leaf protein concentrate. Jpn. J. Zootech. Sci., 55: 584-590. 1984.

11) Peterson DW. Some properties of a factor in alfalfa meal causing depression of growth in chicks. J. Biol. Chem., 183 : 647-653. 1950.

12) Reshef G. Gestetner B, Birk Y, Bondi A. Effect of alfalfa saponins on the growth and some aspects of lipid metabolism of mice and quails. J. Sci. Food Agric., $27: 63-72.1976$.

13) Shany S, Birk Y, Gestetner B, Bondi A. Preparation, characterization and some properties of saponins from lucerne tops and roots. J. Sci. Food Agric., $51: 621-632.1970$.

14) Story JA, LePage SL, Petro MS, West LG, Cassidy MM, Lightfoot FG, Vahouny GV. Interactions of alfalfa plant and sprout saponins with cholesterol in vitro and in cholesterol-fed rats. Am. J. Clin. Nutr., 26 : 27-135. 1984.

15) Ueda $H$, Ohshima M, Kamada $M$. The effects of processing methods and cholesterol addition on the nutritive value of leaf protein concen trates in chicks. Jpn. Poult. Sci., $23: 195-202$. 1986.

16) Ueda H, Ohshima M, Akitomo I. Nutritive value and hypocholesterolemic effect of alfalfa leaf protein concentrates prepared from two different varieties in chicks. Jpn. J. Zootech. 
Sci., $58: 347-355.1987$.

17) Ueda $H$, Ohshima $M$. Nutritive value of alfalfa leaf protein concentrate prepared from low saponin variety in chicks and pigs. Jpn. J. Zootech. Sci., 60 : 561-566. 1989.

18) Ueda $H$, Ohshirna $M$. Nutritive value of alfalfa leaf protein concentrate prepared from high saponin variety by the acid treatment in chicks. Jpn. J. Zootech. Sci, 60 : 639-643. 1989.

19) Ueda H. Effects of dietary protein and soybean saponins on plasma cholesterol concentration in chicks. Anim. Sci. Technol. (Jpn.), $68: 793^{-}$ 799. 1992.

20) Ueda $H$, Ohshima M. Hypocholesterolemic effect of alfalfa leaf protein concentrate and soybean protein isolate in chicks. Anim. Sci. Technol. (Jpn.), 63 : 1032-1037. 1992.

21) Ueda H, Imanishi T, Fukumi R, Kumai S. Effect of dietary lysine and arginine addition on growth performance and serum cholesterol level in chicks. Anim. Sci. Technol. (Jpn.), 66 : 412-421. 1995.

22) Ueda H, Matsumoto A, Goutani S. Effects of soybean saponin and soybean protein on serum cholesterol concentration in cholesterol -fed chicks. Anim. Sci. Technol. (Jpn.), 67 : 415422. 1996.

23) Yoshida M. Design of Experiments for Animal Husbandry. 152-162. Yoken-do. Tokyo. 1975.

\title{
アルファルファサポニン給与によるニワトリヒナの発育阻害
}

\author{
上田博史・角藤義宜・大島光昭*
}

愛媛大学農学部，松山荷 790

*名古屋大学農学部附属農場，愛知県東郷町 470-01

単冠白色レグホン雄ヒナを用い,アルファルファサポニン給与による発育阻書の原因について調べ た. 武験 1 では，カゼインをタンバク質源とする半精製飼料（CP 20\%）を用いて12 日間の飼育試験を 行った. $1 \%$ のサポニン添加は飼料撕取量を隇少し発育も阻害した。しかし，1\%コレステロールをサポ ニンと同時に添加すると，飼料摄取量の減少む成辰阻害もるられなかった，血清中のコレステロールと トリグリセリド濃度はコレステロール添加で上昇し，サポ二ンの添加で減少した。試験 2 では, 味覚の 影響を避けるために，サポニン $0.5 \mathrm{~g}$ をカプセルに入れて腺胃に直接投与し，24時間の飼料摂取量を記 録した，飼料摂取量はサポニン投与で低下したが，等量のコレステロールをカプセルに入れてサポニン と同時に投与するか，あるいはサポニン投与後，1\%コレステロール添加飼料を与えると飼料掑取量は 低下しなかった。試験 3 では, 酸化クロムを添加した飼料を強制給慨し, 酸化クロム非泄量を 24 時間測 定した。 サポニン添加飼料の給与で, 酸化クロム排泄量は対照区の約 $50 \%$ に隇少した。 また, 強制給租 終了後, 12 時間絶食したにもかかからず, サポニン添加区では飼料が嗉变に停滞し, これらのヒナにサ ポニン無添加飼料を自由摄取させても，飼料摃取量は增加しなかった，しかし，コレステロールをサポ ニンと同時に給与すると酸化クロム排泄量す対照区と同じ程度に増加し，自由摄取下でのサポニン無添 加飼料の摄取量も対照区と差がなかった，以上の結果から，サポニン給与による発育阻害とコレステ

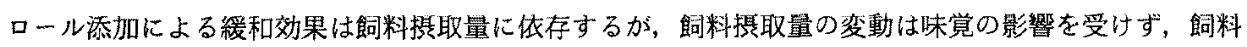
の消化管内通過速度と関連していることが示唆された。 